\title{
Online Based Thesis Guidance Application For Informatics Students During Pandemic
}

\author{
Latius Hermawan', Maria Bellaniar Ismiati ${ }^{2}$ \\ ${ }^{1}$ Musi Charitas Catholic University / Informatics \\ Bangau Street No.60 Palembang, +62711 366326, e-mail: tiuz.hermawan@ukmc.ac.id \\ ${ }^{2}$ Musi Charitas Catholic University / Information System \\ Bangau Street No. 60 Palembang, +62711 366326, e-mail: bella @ukmc.ac.id
}

\section{ARTICLE INFO}

Article history:

Received 26 January 2021

Received in revised form 29 July 2021

Accepted 29 July 2021

Available online 31 July 2021

\begin{abstract}
The Ministry of Education and Culture (Kemendikbud) issued Circular Letter Number 15 of 2020 concerning Guidelines for Organizing Learning from Home in an Emergency for the Spread of Covid19. This causes the learning process that should be done face-to-face, being changed to online. Students must study from home and carry out the online thesis guidance process. Some of the difficulties experienced by students during direct mentoring, namely the difficulty of meeting lecturers who are busy teaching or doing assignments from institutions, besides that students who come from outside the city have to go back and forth just to meet the supervisor.. One of the ways to solve this problem is by applying technology. Currently there is web technology that can be used to easily develop applications, namely the concept of a framework approach. With the existence of an online-based application which is the role of current technological developments, it will make the thesis guidance process carried out by lecturers and students more flexible. Students are able to carry out the guidance process anywhere and anytime.
\end{abstract}

Keywords: guidance, website, document, task

\section{Pendahuluan}

Kementerian Pendidikan dan Kebudayaan (Kemendikbud) mengeluarkan Surat Edaran Nomor 15 Tahun 2020 tentang Pedoman Penyelenggaraan Pembelajaran Dari Rumah Pada Saat Darurat Penyebaran Covid-19. Staf Ahli Peraturan Menteri Pendidikan dan Kebudayaan, Chatarina Muliana Girsang menyampaikan Surat Edaran Nomor 15 ini untuk Penguatan Surat Edaran Menteri Pendidikan dan Kebudayaan Nomor 4 Tahun 2020 Tentang Penyelenggaraan Pendidikan Pada Masa Darurat Penyakit Virus Corona [5]. Hal ini menyebabkan proses pembelajaran yang seharusnya dilakukan secara tatap muka, berubah menjadi online. Ada beberapa dampak yang terjadi akibat peraturan tersebut, salah satunya adalah pendidikan tinggi sedalam-dalamnya [3][6][10]. Mahasiswa harus belajar dari rumah dan melakukan proses bimbingan skripsi secara online. Beberapa kesulitan yang dialami mahasiswa pada saat bimbingan langsung yaitu sulitnya menemui dosen yang sedang sibuk mengajar atau mengerjakan tugas dari institusi, selain itu mahasiswa dari luar kota harus bolak-balik hanya untuk menemui dosen pembimbing. 13][3]. Para dosen juga mengalami kesulitan dalam memantau status bimbingan mahasiswa karena harus

Received January 26, 2021; Revised July 29, 2021; Accepted July 29, 2021 
merekapitulasi satu persatu dan terkadang ada beberapa mahasiswa yang tidak aktif dalam status bimbingannya sudah berada di luar kampus atau sudah bekerja [6][7]. Salah satu cara untuk mengatasi masalah tersebut adalah dengan penerapan teknologi.

Perkembangan Ilmu Pengetahuan dan Teknologi khususnya di bidang teknologi komputer memegang peranan yang sangat penting dalam berbagai aspek kehidupan [11][12]. Perkembangan teknologi komputer membutuhkan kemampuan sumber daya manusia untuk dapat menguasai dan mengikuti perkembangan teknologi komputer. Teknologi informasi berkembang sangat pesat salah satunya teknologi web. Saat ini terdapat teknologi web yang dapat digunakan untuk mengembangkan aplikasi dengan mudah dengan konsep pendekatan framework [1][2][9]. Dengan adanya aplikasi berbasis online yang menjadi peran perkembangan teknologi saat ini akan membuat proses bimbingan skripsi yang dilakukan dosen dan mahasiswa bisa lebih fleksibel. Mahasiswa mampu melakukan proses bimbingan dimanapun dan kapanpun. Dosen yang membimbing juga bisa membantu bimbingan mahasiswa dengan mudah tanpa takut tertular virus corona. Penularan virus corona yang sedang berlangsung juga dapat dikendalikan dengan menerapkan pembinaan secara online, sehingga proses pendidikan juga dapat terus berjalan.

Berdasarkan permasalahan tersebut, peneliti akan membangun sebuah aplikasi berbasis online dengan judul "Aplikasi Bimbingan Skripsi Berbasis Online Untuk Mahasiswa Selama Pandemi" untuk membantu menyelesaikan permasalahan tersebut di Universitas Katolik Musi Charitas yang juga menerapkan proses belajar dari rumah.

\section{Research Method}

Dalam mengumpulkan data-data yang dibutuhkan untuk pengembangan sistem Informasi Bimbingan Skripsi, metode yang digunakan yaitu :

\section{Pengamatan}

Metode Observasi Observasi merupakan varian dari pengumpulan data pilihan metode, yang memiliki karakteristik metodologis yang kuat. Metode observasi tidak hanya proses mengamati kegiatan dan pencatatan, tetapi juga observasi memudahkan kita untuk memperoleh informasi tentang dunia di sekitar kita. Metode observasi dapat diintegrasikan dengan metode lain, sehingga tingkat ketelitiannya dapat diperhatikan.

\section{Studi Dokumentasi}

Studi Dokumentasi adalah sejenis teknik pengumpulan data, dengan kemampuan mengumpulkan dan menganalisis literatur, baik literatur tertulis, gambar, karya maupun bentuk elektronik. Kemudian menganalisis, membandingkan dan menggabungkan (mensintesis) dokumen-dokumen yang diperoleh menjadi suatu kajian yang sistematis, komprehensif dan utuh.

Jika mahasiswa telah memenuhi persyaratan, penanggung jawab rencana studi dapat memperoleh sistem yang sedang berjalan sebelum mengajukan judul makalah yang diajukan oleh mahasiswa selama pandemi dan proses bimbingan esai. Sistem mendaftarkan makalah judul mahasiswa dan melampirkan makalah yang disarankan dengan mengisi formulir. Menyerahkan surat-surat yang diperlukan. Kemudian, jika judul "mahasiswa" disetujui oleh penanggung jawab rencana studi, mahasiswa tersebut akan diberitahukan dalam bentuk usulan jadwal sidang. Dalam proses penyelesaian dan pemantauan penulisan esai, mahasiswa didampingi oleh pembimbing. Pembimbing setiap mahasiswa ditunjuk oleh penanggung jawab rencana studi.

Pembinaan skripsi harus diselesaikan secara tatap muka antara tutor dan mahasiswa, yang hanya bisa dilakukan di kampus. Ketika social distancing saat ini melindungi tubuh dari virus corona, proses yang dipandu oleh skripsi ini tidak bisa berjalan mulus. Oleh karena itu, kendala ini akan menimbulkan permasalahan dalam penulisan skripsi yang tidak dapat segera diselesaikan.

Kegiatan penelitian ini akan dilaksanakan dalam waktu satu semester. Secara keseluruhan, kegiatan penelitian akan dibagi menjadi lima tahapan penelitian. Berikut ini adalah uraian singkat dari masing-masing tahapan penelitian dengan menggunakan model waterfall. 


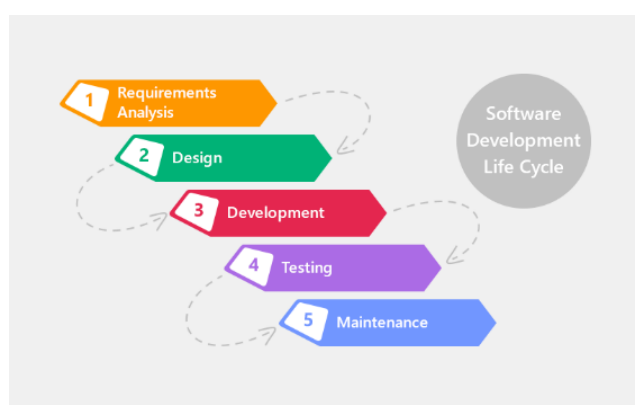

Gambar 1. Waterfall Process

1. Tahap I : Pada tahap ini akan dilakukan identifikasi kebutuhan secara lebih mendalam. Hasil yang diharapkan dari tahapan ini adalah daftar identifikasi, baik kebutuhan fungsional maupun nonfungsional.

2. Tahap II : Berdasarkan identifikasi kebutuhan yang telah dibuat, pada tahap ini akan dilakukan analisis terhadap perangkat lunak yang akan dibangun. Hasil analisis berupa perangkat lunak pemodelan yang siap untuk dirancang. Data Flow Diagram dan Entity Relationship Diagram akan menjadi salah satu acuan dalam pembuatan aplikasi ini.

3. Tahap III : Model perangkat lunak yang telah dibuat pada tahap II akan diterjemahkan ke dalam desain perangkat lunak yang siap untuk dikodekan dengan bahasa pemrograman HTML, CSS, PHP, MySQL, Javascript.

4. Tahap IV : Pada tahap ini akan dilakukan pengkodean perangkat lunak. Hasil dari kegiatan ini adalah sebuah software berupa website. Website yang sudah di generate akan dicocokkan kembali sesuai kebutuhan untuk mengatasi masalah tersebut.

5. Tahap V : Pada tahap ini akan dilakukan pengujian website terhadap pengguna aplikasi. Pengguna adalah mahasiswa tingkat akhir yang akan mengerjakan skripsi.

\section{Data Flow Diagram}

Diagram konteks ini menggambarkan aliran data dari kesatuan luar ke dalam sistem, secara garis besar atau keseluruhan. Diagram konteks sistem informasi bimbingan skripsi berbasis web dapat dilihat pada gambar berikut [8]. ERD merupakan diagram untuk menggambarkan rancangan konsep dari model konseptual suatu basis data relasional. Menurut [8] Entity Rational Diagram menggambarkan makna dari aspek-aspek data seperti bagaimana entitas, atribut dan relasinya disajikan. Gambar 2 merupakan diagram entitas rasional dari sistem informasi panduan tugas akhir.

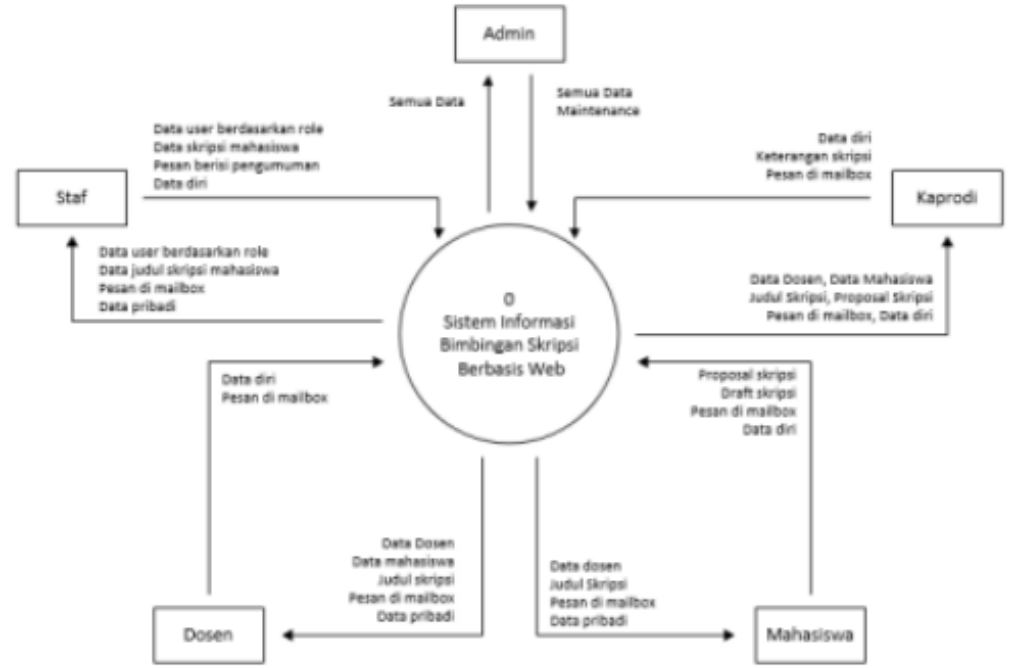

Gambar 2. Data Flow Diagram

TRANSFORMATIKA Vol. 19, No. 1, July 2021: $64-73$ 


\section{Database Relationship}

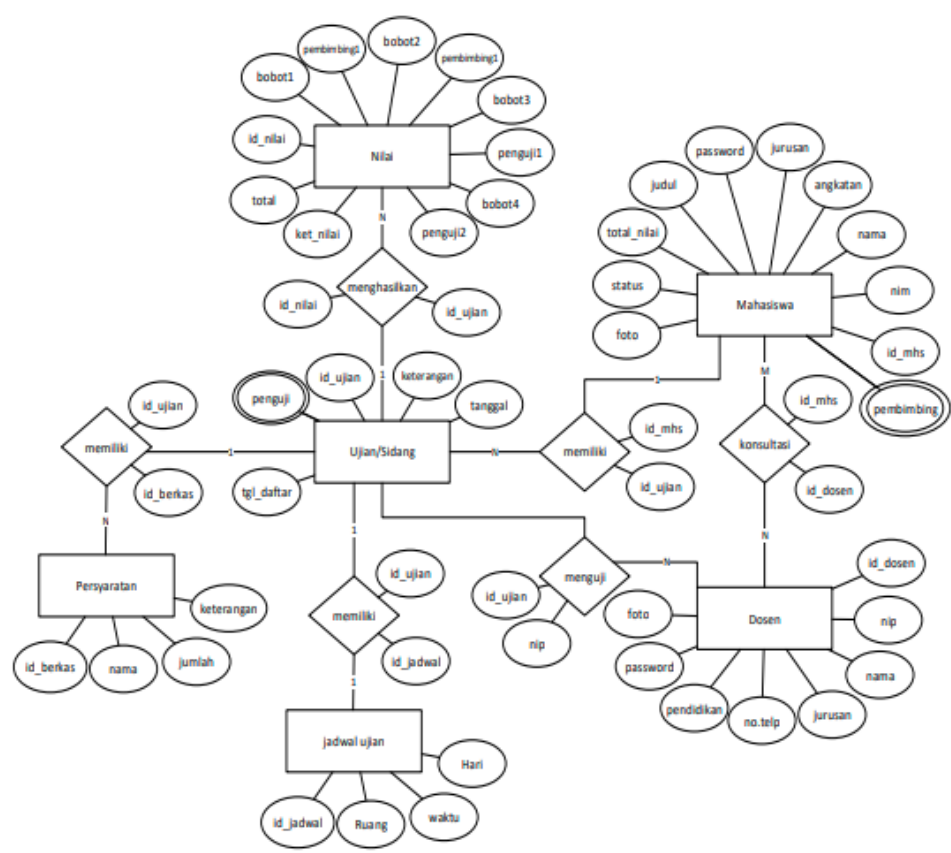

Gambar 3. Database Relationship

\section{Hasil dan Pembahasan}

Tampilan Awal Aplikasi

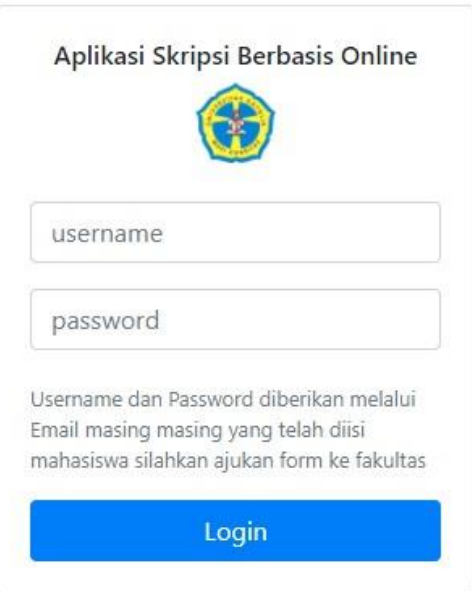

\section{Gambar 4. Tampilan Login}

Gambar di atas menunjukkan halaman awal dari aplikasi yang telah dibuat. Aplikasi ini merupakan halaman login untuk semua pengguna aplikasi mulai dari Admin, Ketua Program Studi, Dosen Pembimbing dan Mahasiswa. Setiap akun harus memasukan username dan password agar dapat menggunakan aplikasi ini sesuai dengan hak akses masing-masing. Pada awalnya admin akan membuatkan akun untuk setiap pengguna dari aplikasi. Sistem akan mengecek apakah data yang dimasukan benar, jika benar maka pengguna dapat masuk ke sistem, jika salah, maka pengguna tidak dapat masuk ke sistem atau mengecek kesalahan masukan pada username ataupun password. 


\section{Bagian Admin - Tambah Data Mahasiswa

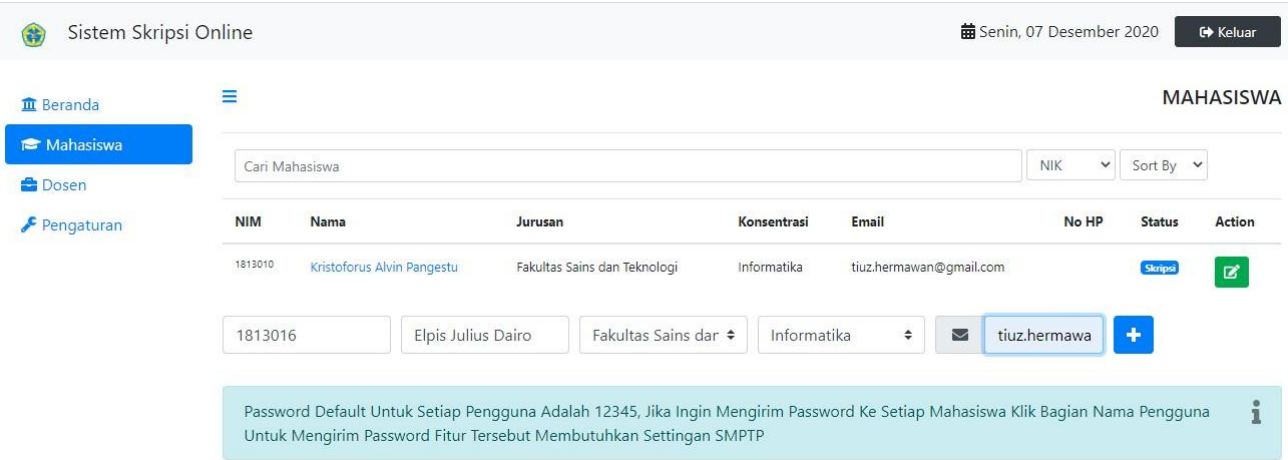

Gambar 5. Bagian Admin - Tambah Data Mahasiswa

Gambar diatas menunjukkan halaman awal admin yang berfungsi untuk menambah mahasiswa yang akan menjalani proses skripsi di kampus. Komponen yang diinput mulai dari NIM, NamaMahasiswa dan KontakMahasiswa. Data tersebut akan membuat mahasiswa dapat login ke sistem untuk proses pengajuan skripsinya.

\section{Bagian Mahasiswa - Notifikasi Status Proposal Skripsi

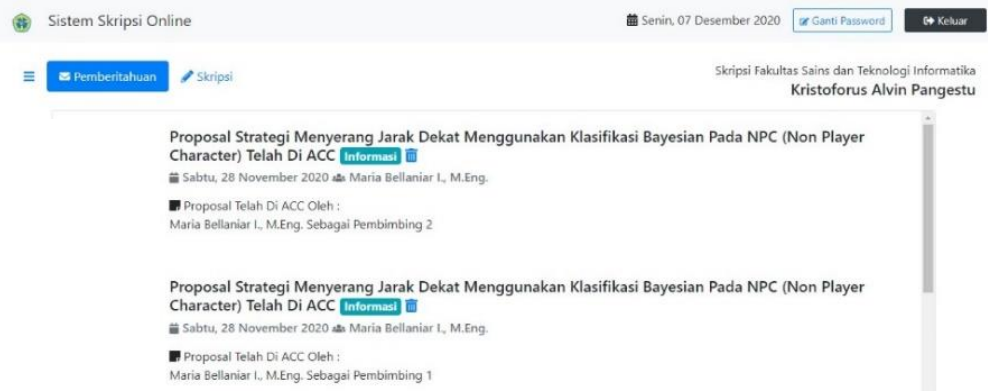

Gambar 6. Bagian Mahasiswa - Notifikasi Status Proposal Skripsi

Gambar di atas menunjukkan halaman awal mahasiswa yang digunakan untuk melihat semua informasi yang berkaitan dengan skripsi mulai dari pengajuan proposal, bimbingan hingga jadwal sidang skripsi. Pengumuman disini adalah hasil dari inputan admin dan dosen pembimbing yang telah menyetujui proposal skripsi tersebut.

\section{Bagian Mahasiswa - Detil Notifikasi Status Pengajuan Proposal Skripsi}

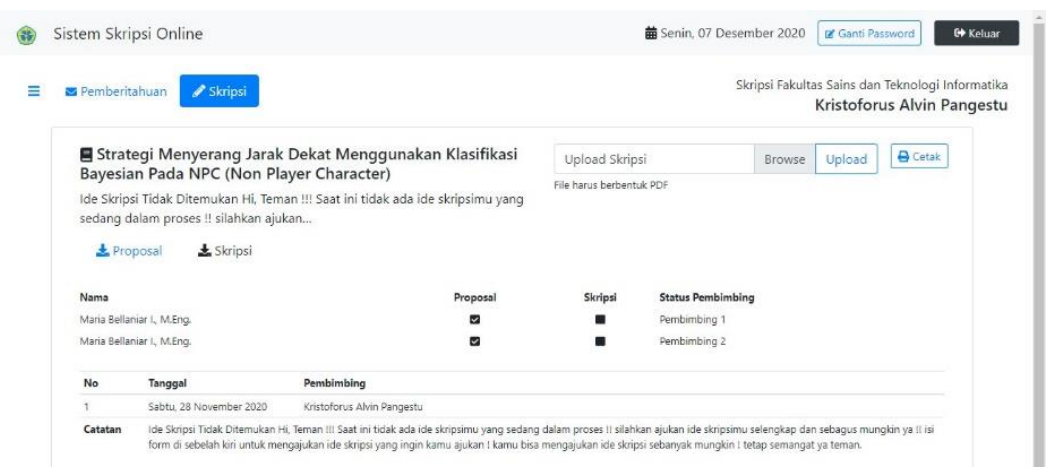

Gambar 7. Bagian Mahasiswa - Detil Notifikasi Status Pengajuan Proposal Skripsi

TRANSFORMATIKA Vol. 19, No. 1, July 2021: $64-73$ 
Gambar di atas menunjukkan halaman awal mahasiswa yang digunakan untuk melihat semua informasi yang berkaitan dengan bimbingan skripsi mulai dari pengajuan proposal yang dilakukan oleh mahasiswa, bimbingan yang dilakukan mahasiswa ke dosen secara daring hingga laporan proposal dan skripsi yang telah disetujui oleh semua dosen pembimbing dan menunggu jadwal untuk sidang akhir skripsi. Hal ini akan mempermudah proses penyelesaian proses skripsi dimasa pandemi.

\section{Bagian Mahasiswa - Pengajuan Proposal Ke Kaprodi}

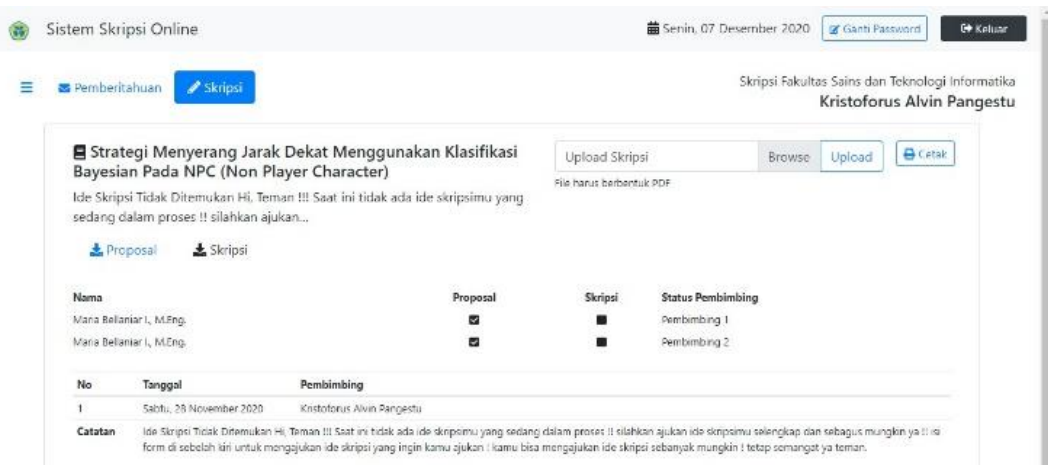

\section{Gambar 8. Bagian Mahasiswa - Pengajuan Proposal Ke Kaprodi}

Gambar di atas menunjukkan halaman awal mahasiswa yang berfungsi untuk mengajukan ide skripsi yang ditujukan kepada Ketua Program Studi untuk disetujui dan diberikan oleh dosen pembimbing. Mahasiswa akan melakukan upload berkas proposalnya dengan format doc/pdf, yang selanjutnya akan dilakukan proses upload data ke sistem, sehingga nantinya dosen pembimbing dapat melihat proposal skripsi secara lengkap dari awal hingga proses revisi proposalnya.

\section{Bagian Kaprodi - Penetapan Dosen Pembimbing Skripsi}

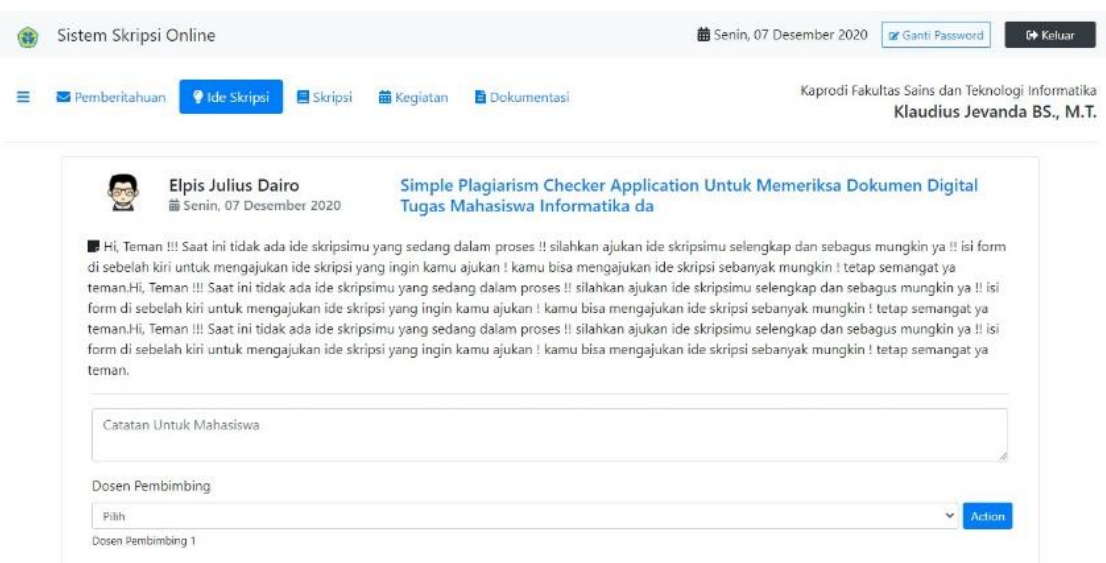

Gambar 9. Bagian Kaprodi - Penetapan Dosen Pembimbing Skripsi

Gambar di atas menunjukkan halaman kepala Program Studi dengan Gagasan Skripsi yang sebelumnya diajukan oleh Mahasiswa. Jika diterima, Ketua Program Studi dapat segera memberikan catatan dan menentukan pembimbing sesuai program studi. Jika ditolak, Ketua Program Studi dapat menekan tombol Tindakan dan memilih untuk menolak Proposal Ide Skripsi. Hasil dari proses ini akan langsung ditampilkan ke mahasiswa yang dituju, mahasiswa akan menerima notifikasi pada akun mahasiswa setelah login. 


\section{Bagian Pembimbing - Pembimbingan Skripsi Nahasiswa}

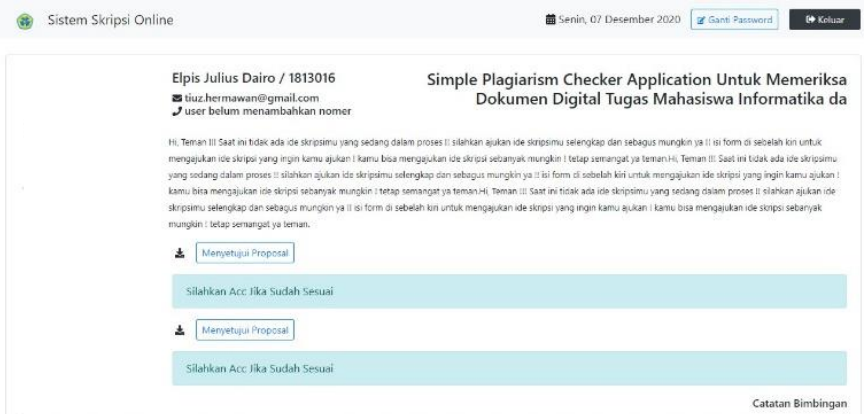

\section{Gambar 10. Bagian Pembimbing - Pembimbingan Skripsi Nahasiswa}

Gambar di atas menunjukkan halaman awal bimbingan belajar yang digunakan untuk melakukan bimbingan skripsi dengan mengunduh laporan yang di upload mahasiswa dan selanjutnya memasukkan catatan setelah proses membaca laporan yang diunduh dan mengunggah file yang diperlukan. Setelah selesai, setiap dosen pembimbing dapat menyetujui proposal dan skripsi dengan menekan tombol yang telah disediakan. Dosen pembimbing dapat melakukan proses ini secara berulang hingga proposal ataupun skripsi sudah dianggap layak untuk diselesaikan. Hasil dari proses ini akan langsung ditampilkan ke mahasiswa yang dituju, mahasiswa akan menerima notifikasi pada akun mahasiswa setelah login.

\section{Pengujian Aplikasi ke Pengguna}

Pengujian beta adalah pengujian yang dijalankan secara objektif dimana aplikasi diuji langsung ke pengguna yang relevan [5]. Pengujian dilakukan dengan menyebarkan kuesioner kepada 25 orang yang diwawancarai. Narasumber tes adalah mahasiswa dan dosen terkait dalam kegiatan bimbingan pekerjaan rumah akhir. Dengan mengajukan beberapa pertanyaan sesuai dengan aspek. Tanggapan responden untuk semua aspek memenuhi standar yang sesuai yang ditunjukkan pada Tabel 3.1. (Informasi: $5=$ Sangat Baik, $4=$ Baik, $3=$ Cukup, $2=$ Buruk, $1=$ Sangat Kurang).

Table 1. Beta Testing

\begin{tabular}{|c|c|c|c|c|c|c|c|}
\hline No & Aspek Komunikasi Visual & Skor 1 & Skor 2 & Skor 3 & Skor 4 & Skor 5 & Total \\
\hline 1 & Tampilan Aplikasi & 0 & 0 & 4 & 15 & 6 & 25 \\
\hline 2 & Tampilan Menu Aplikasi & 0 & 1 & 6 & 16 & 2 & 25 \\
\hline 3 & Huruf Mudah Dibaca & 0 & 0 & 3 & 13 & 9 & 25 \\
\hline 4 & Kombinasi Warna & 0 & 0 & 10 & 10 & 5 & 25 \\
\hline \multirow[t]{2}{*}{5} & Respon Aplikasi Sesuai Input & 0 & 0 & 3 & 10 & 12 & 25 \\
\hline & Aspek Fungsionalitas & & & & & & \\
\hline 1 & Kinerja Aplikasi Saat Berjalan & 0 & 0 & 5 & 12 & 8 & 25 \\
\hline 2 & Kinerja Sistem Notifikasi & 0 & 0 & 6 & 16 & 3 & 25 \\
\hline \multirow[t]{2}{*}{3} & $\begin{array}{c}\text { Kinerja Aplikasi Menangani } \\
\text { Manajemen Data }\end{array}$ & 0 & 0 & 1 & 22 & 2 & 25 \\
\hline & Aspek RPL & & & & & & \\
\hline 1 & $\begin{array}{c}\text { Kemudahan Menjalankan } \\
\text { Aplikasi }\end{array}$ & 0 & 0 & 1 & 12 & 12 & 25 \\
\hline 2 & Kompabititas Aplikasi & 0 & 0 & 7 & 10 & 8 & 25 \\
\hline 3 & $\begin{array}{l}\text { Kelancaran Menjalankan } \\
\text { Aplikasi }\end{array}$ & 0 & 0 & 3 & 10 & 12 & 25 \\
\hline 4 & Kemudahan Mengakses Fitur & 0 & 0 & 1 & 13 & 11 & 25 \\
\hline
\end{tabular}

TRANSFORMATIKA Vol. 19, No. 1, July 2021: $64-73$ 


\begin{tabular}{|c|c|c|c|c|c|c|c|}
\hline 5 & $\begin{array}{c}\text { Kenyamanan Menggunakan } \\
\text { Aplikasi }\end{array}$ & 0 & 0 & 0 & 20 & 5 & 25 \\
\hline
\end{tabular}

Pada Tabel 3.1 dapat ditemukan informasi, antara lain:

1. Jumlah skor untuk setiap responden:

- Skor maksimum $=65$ (5 x 13 item),

- Skor minimum $=13$ (1 x 13 item),

- Skor median $=39(3 \times 13$ item $)$,

- Skor kuartil I = 26 ( 2 x 13 item),

- Skor kuartil III = 52 (4 x 13 item)

2. Total skor untuk semua responden:

- Maksimum $=1625$ (25 x 65),

- Minimum $=325$ ( $25 \times 13)$,

- Median $=975(25 \times 39)$,

- Kuartil I = 650 ( $25 \times 26)$,

- Kuartil III = 1300 (25 x 52)

Data yang diperoleh dari hasil pengujian dengan kuesioner diukur dengan skala Likert's Summated Rating (LSR). Metode LSR digunakan untuk mengukur sikap, opini dan persepsi seseorang atau sekelompok orang tentang fenomena sosial [8]. Interpretasi dari skor total adalah:

$-1300<$ Skor $<=1625$, artinya sangat positif (aplikasi dinilai berhasil)

- $975<$ Skor $<=1300$, yang artinya positif (aplikasi dinilai cukup berhasil)

$-650<$ Skor $<=975$, artinya negatif (permohonan dinilai kurang berhasil)

$-325<$ Skor $<=650$, artinya sangat negatif (aplikasi tidak berhasil)

Hasil penelitian dengan skor 1343 yang berada pada rentang sangat positif, sehingga aplikasi dinyatakan berhasil

\section{Testing Program}

\begin{tabular}{|l|l|l|c|}
\hline No. & Komponen Uji & \multicolumn{1}{c|}{ Table 3.2. Testing Table } & Hasil Pengujian \\
\hline $\mathbf{1}$ & Halaman Login & Pengguna mampu login sesuai dengan hak akses & Terpenuhi \\
\hline $\mathbf{2}$ & Halaman Mahasiswa & $\begin{array}{l}\text { Tampil Informasi mengenai Perkembangan } \\
\text { Skripsi }\end{array}$ & Terpenuhi \\
\hline $\mathbf{3}$ & Halaman Mahasiswa & $\begin{array}{l}\text { Mahasiswa mampu melihat proses } \\
\text { pembimbingan. }\end{array}$ & Terpenuhi \\
\hline $\mathbf{4}$ & Halaman Mahasiswa & $\begin{array}{l}\text { Mahasiswa mampu Upload proposal dan laporan } \\
\text { Skripsi dan melihat jadwal sidang }\end{array}$ & Terpenuhi \\
\hline $\mathbf{5}$ & Halaman Mahasiswa & Mahasiswa mampu mengusulkan Ide Skripsi & Terpenuhi \\
\hline $\mathbf{6}$ & Halaman Mahasiswa & Mahasiswa mampu mencetak kartu bimbingan & Terpenuhi \\
\hline $\mathbf{7}$ & Halaman Pembimbing & $\begin{array}{l}\text { Dosen mampu memberikan catatan } \\
\text { pembimbingan }\end{array}$ & Terpenuhi \\
\hline
\end{tabular}




\begin{tabular}{|c|c|c|c|}
\hline 8 & Halaman Pembimbing & $\begin{array}{l}\text { Dosen mampu menyetujui laporan } \\
\text { proposal/skripsi }\end{array}$ & Terpenuhi \\
\hline 9 & Halaman Kaprodi & $\begin{array}{l}\text { Kaprodi Mampu melihat Usulan Ide Skripsi } \\
\text { Mahasiswa }\end{array}$ & Terpenuhi \\
\hline 10 & Halaman Kaprodi & $\begin{array}{l}\text { Kaprodi Mampu menyetujui Usulan Ide Skripsi } \\
\text { Mahasiswa dan Menentukan Dosen Pembimbing }\end{array}$ & Terpenuhi \\
\hline 11 & Halaman Kaprodi & $\begin{array}{l}\text { Kaprodi Mampu membuat jadwal sidang } \\
\text { proposal dan Skripsi }\end{array}$ & Terpenuhi \\
\hline 12 & Halaman Kaprodi & $\begin{array}{l}\text { Kaprodi mampu melihat proses pembimbingan } \\
\text { seluruh mahasiswa yang aktif skripsi }\end{array}$ & Terpenuhi \\
\hline 13 & Halaman Admin & Menambah mahasiswa yang akan skripsi & Terpenuhi \\
\hline 14 & Halaman Admin & $\begin{array}{l}\text { Menambah daftar dosen yang akan membimbing } \\
\text { skripsi }\end{array}$ & Terpenuhi \\
\hline 15 & Halaman Admin & $\begin{array}{l}\text { Menambah daftar fakultas dan program studi } \\
\text { yang ada }\end{array}$ & Terpenuhi \\
\hline 16 & Halaman Admin & Menyesuaikan Kaprodi pada setiap fakultas & Terpenuhi \\
\hline
\end{tabular}

\section{Kesimpulan}

Secara umum aplikasi yang dibuat sudah berjalan dengan baik, dibuktikan dengan kuisioner yan gtelah diisi oleh responden. Tampilan dan fungsionalitas aplikasi juga dapat berjalan dengan baik untuk melakukan proses pengajuan, pembimbingan proposal dan skripsi dengan baik, sehingga dapat mempermudah mahasiswa dan dosen pembimbing serta kaprodi. Adanya sistem bimbingan skripsi berbasis online akan membantu mengurangi dampak kontak fisik di masa pandemi seperti ini. Sistem ini memiliki user-interface yang cukup menarik dan mudah digunakan.

\section{References}

[1] Betha Sidik. "Pemrograman Web Dengan PHP". 2012. Informatika,. Bandung.

[2] Dipanegara, A. "Langsung Jago Bikin Website-Gratis Dengan Web". 2011. Agogos Publishing, Jakarta.

[3] Dwiyani, A. "Perancangan Sistem Pendukung Bimbingan Online Tugas Akhir Mahasiswa Program Studi Teknik Informatika, 1-5". 2013. Justin (Jurnal Sistem Dan Teknologi Informasi) Universitas Tanjungpura

[4] Jogiyanto. 2005. Analisis Dan Desain Sistem Informasi. Yogyakarta.

[5] Kemdikbud. "Kemendikbud Terbitkan Pedoman Penyelenggaraan Belajar Dari Rumah". 2020. Kemdikbud : Jakarta

[6] Nugroho, K. "Rancang Bangun Aplikasi Mobile Bimbingan Dan Monitoring Tugas Akhir (Studi Kasus Stikes Estu Utomo Boyolali)". 2017. INFOKAM No.II Th.XIII/September/2017

[7] Patimah, S. "Aplikasi Manajemen E-Skripsi Online (Studi Kasus Prodi Sistem Informasi Universitas Islam Indragiri)". 2017. Jurnal Sistem Informasi Universitas Islam Indragiri

[8] Pressman, Roger S. "Software Engineering : A Practitioner's Approach. (7th. Edition)”. 2010. New York: Mcgraw-Hill Higher Education.

[9] Riehle, D. "Framework Design: A Role Modeling Approach". 2000. Ph.D. Thesis, No. 13509.Zürich, Switzerland, Eth Zurich. 
[10] Salamah, I. "Aplikasi Bimbingan Tugas Akhir Menggunakan Notifikasi Berbasis Android". 2019. Jurnal Media Informatika Budidarma No.3 Vol.3, Juli 2019

[11] Setiawan, R. "Implementasi Sistem Pengelolaan Skripsi Online Pada Program Studi Teknik Informatika". 2017. Prosiding Snatif Ke-4 Tahun 2017

[12] Utariani. "Monitoring Bimbingan Skripsi Online Pada Sekolah Tinggi Manajemen Informatika Dan Komputer (Stmik) Palangka Raya". 2018. Stmik Palangka Raya

[13] Wijaya, L. "Rancang Bangun Aplikasi Bimbingan Skripsi Berbasis Web Mobile". 2019. Jurnal Teknologi Informasi Mura Vol 11 No.02, Desember 2019 